\title{
A theoretical framework of chain management
}

\author{
Jon Hanf ${ }^{1}$ and Kirsti Dautzenberg ${ }^{2}$ \\ ${ }^{1}$ Leibniz-Institute of Agricultural Development in Central and Eastern Europe, Department: Agricultural Markets, Marketing and \\ World Agricultural Trade, Theodor-Lieser-Str. 2, 06120 Halle (Saale), Germany, hanf@iamo.de \\ ${ }^{2}$ Leibniz-Institute of Agricultural Development in Central and Eastern Europe, Department: Structural Development of Farms and \\ Rural Areas, Theodor-Lieser-Str. 2, 06120 Halle (Saale), Germany,dautzenberg@iamo.de
}

\begin{abstract}
Strictly coordinated chain organisations have been in place in the agri-food business for many years. The majority of them are collaborative. These organisations have a pyramidal-hierarchical structure. A focal firm, which is centrally located, coordinates the network firms in a hierarchical style. Our paper aims to develop a managerial framework for networks, and we address cooperation as well as coordination. Gulati et al. (2005) conclude that even though cooperation may be achieved, i.e., the interests of the individual actors are aligned, coordination problems may persist. Thus, both the alignment of interests and the alignment of actions must be simultaneously achieved to create a successful partnership; they can be viewed as two sides of the same coin. Duysters et al. (2004) have shown that the management of alliances must be analysed on three levels: the firm, dyadic, and network levels. We have therefore combined the aspects of cooperation and coordination with these three levels. Because the focus of our paper is on the development of a theoretical chain management concept, we applied this concept to a case study. We are aware that this is not empirical evidence, but nonetheless it confirmed our findings. The case of a supply chain network of a German premium pasta manufacturer showed that the combination of cooperation and coordination with a differentiated view of the various network levels corresponds with the demands of real business life.
\end{abstract}

Keywords: food chain management, cooperation, coordination, network levels

\section{Introduction}

Food products are usually not produced in vertically integrated food chains, but rather in vertical cooperating networks. This is due to the varying sizes of firms along the food chain. Incentives for collaboration include inter-firm potentials, reduced or shared risk (including income risk) and the use of economics of scope. Moreover, verticalisation of the agri-food business has also become important because the quality perceptions of both consumers and politicians have changed, so that quality is no longer the concern of a single firm. Instead, the entire food chain must work together (Boehlje, 1999; Hanf and Hanf, 2005).

Although networks have been the object of intensive scientific research for many years (e.g. Dyer and Singh, 1998; Gulati and Gargiulo, 1999; Gulati et al., 2000; Inkpen and Tsang, 2005), there is still no consensus on elementary characteristics such as the number of actors required to constitute a network or the autocracy of a network's companies (Kasperzak, 2004). This disagreement on the definition of a network extends to the issue of the essential aspects of networks. Definitions based on transaction cost theory view virtually every hybrid firm system as a network, while sociology-based definitions view networks as a stand-alone organisational form (Kasperzak, 2004). Burr (1999) takes a more differentiating approach to networks, and classifies networks into four typologies: the spontaneous network, the self-organising network, the project-orientated network and the strategic network. These typologies are derived from the intensity of the relationship, the coordination and the existence of a focal firm.

We will use the term "network" in the following sense: networks are composed of interorganisational ties that are enduring and of strategic significance for the firms entering them (Gulati et al., 2000). In general, networks consist of more than two firms (Omta et al., 2001). In addition, the repeating and enduring relationship of the actors in the network (Podolny and Page, 1998) is a key characteristic. Strictly coordinated vertical linkages in the agri-food business are necessary to guarantee credence attributes to consumers, gain cost advantages and reduce and share risk. Such networks can be characterised as pyramidalhierarchic collaborations (Jarillo, 1988), with a focal firm that coordinates the network in a hierarchical style. The intensity of the relationships in such networks is rather high and inherently contains recurrent interactions (Burr, 1999). We will use the term "supply chain networks" (SCN) for this kind of strictly coordinated food system (Zylbersztajn and Farina, 1999).

The focal firm is generally a firm that is identified by consumers as being "responsible" for the specific food item. The other network actors usually depend heavily on 
the focal company because of explicit or implicit contracts, which may be long term. Mutual dependencies exist and the supplying organisations recover some power from the focal company (Medcof, 2001) when the focal organisation itself depends on critical inputs from its suppliers. The argumentation of the resource dependency theory (Pfeffer and Salancik, 1978) is evident if the procurement relationships in today's agri-food business are taken into account. The highly specialised equipment of the processing firms requires agricultural inputs with continuously high specifications, so the processors cannot change suppliers frequently.

Nevertheless, because the focal company is the core element of the SCN, it also has the power to align the actions of the network partners. It can manage the network to realise its strategic objectives (Neves, 2003). This managerial task can be divided into two domains - the tasks of cooperation and coordination. Cooperation problems stem from conflicts of interest and may cause motivation problems (Gulati $e t$ al., 2005). Coordination problems refer to difficulties with aligning the actions of independent firms resulting from a lack of shared and accurate knowledge about decision rules that the other parties are likely to use, as well as the unawareness of existing interdependences.

Thus, our paper aims to develop a theoretical framework of chain management that combines the aspects of collective strategies with those of cooperation and coordination.

\section{Conceptualisation of chain management}

Due to the verticalisation in the agri-food business process, the organisations that evolve can be characterised as supply chain networks with focal firms that are expected to manage the system to realise its strategic objectives. For this purpose, systematic approaches - known as collective strategies - must be jointly developed and implemented (e.g. Astley, 1984; Bresser and Harl, 1986; Carney, 1987). They are regarded as instruments that deal with variations in the inter-organisational environment. Such strategies can be reactive, where they absorb variation within an environment, or they can be proactive, where they forestall unpredictable behaviour by other organisations (Astley and Fombrun, 1983).

Food supply chain networks consist of a number of consecutive stages, and at any stage one or more independent firms must interact with each other. Therefore, the networks not only have to manage the conflicts of individual interests that arise, but they must also address the interdependent actions of the actors (Gulati et al., 2005). The conflicts of individual interests are a cooperation problem, while the adjustment of actions is a coordination problem.
The cooperation problem of aligning the interests of individual partners is addressed by collective strategies concerning partnering, a term that deals with the design of relationships within a supply chain. Regarding supply chain networks and the heterogeneity of their member firms, it can be expected that the optimal mode of partnerships varies widely along the chain. Webster (1992) proposed a continuum ranging from independent partnerships to strategic partnerships. Strategic partnering is defined as an "on-going, long-term, inter-firm relationship for achieving strategic goals, which delivers value to customers and profitability to partners," (Mentzer et al., 2000: 550). Independent partnering is defined as a "needed, shortterm relationship for obtaining parity with competitors," (Mentzer et al., 2000: 550); thus, it aims to improve operational efficiency and effectiveness.

The second reason to implement collective strategies is to overcome the coordination difficulties that arise from interdependency among the firms. In general, interdependency is created when decisions and actions by one partner influence the decisions and actions of partnering firms (Theuvsen, 2004). There are three types of interdependencies: pooled, sequential, and reciprocal (Astley and Fombrun, 1983; Thompson, 1967). In the context of vertical networks in the agri-food business, Lazzarini et al. (2001) recommend exerting managerial discretion for sequential interdependencies, standardising the process for pooled interdependencies and coordinating reciprocal interdependencies through mutual adjustments. Overall, such mechanisms aim to foster the alignment of the actions of the various network actors.

Another reason for installing a common coordination mechanism is to solve the problem of not knowing how the other network actors will behave. Joint decisionmaking processes and creating a hierarchy are examples of mechanisms that address this problem. Such coordination mechanisms are generally implemented in supply chain management strategies.

The focal firm focuses pyramidal-hierarchical collaborations in the agri-food business. It must therefore manage the entire network by establishing a network management system. In our opinion such a network management system should consist of a collective strategy that addresses mechanisms to overcome problems of cooperation and coordination.

As Figure 1 shows, the overall collective strategy establishes the structure of the chain management concept. Both the partnering and supply chain management strategies are derived from the collective strategy. Beside these three strategic elements, our concept includes the mechanisms and instruments to solve the problems of cooperation and coordination. To create a successful collaboration, both the mechanisms of aligning interests (cooperation) as well 


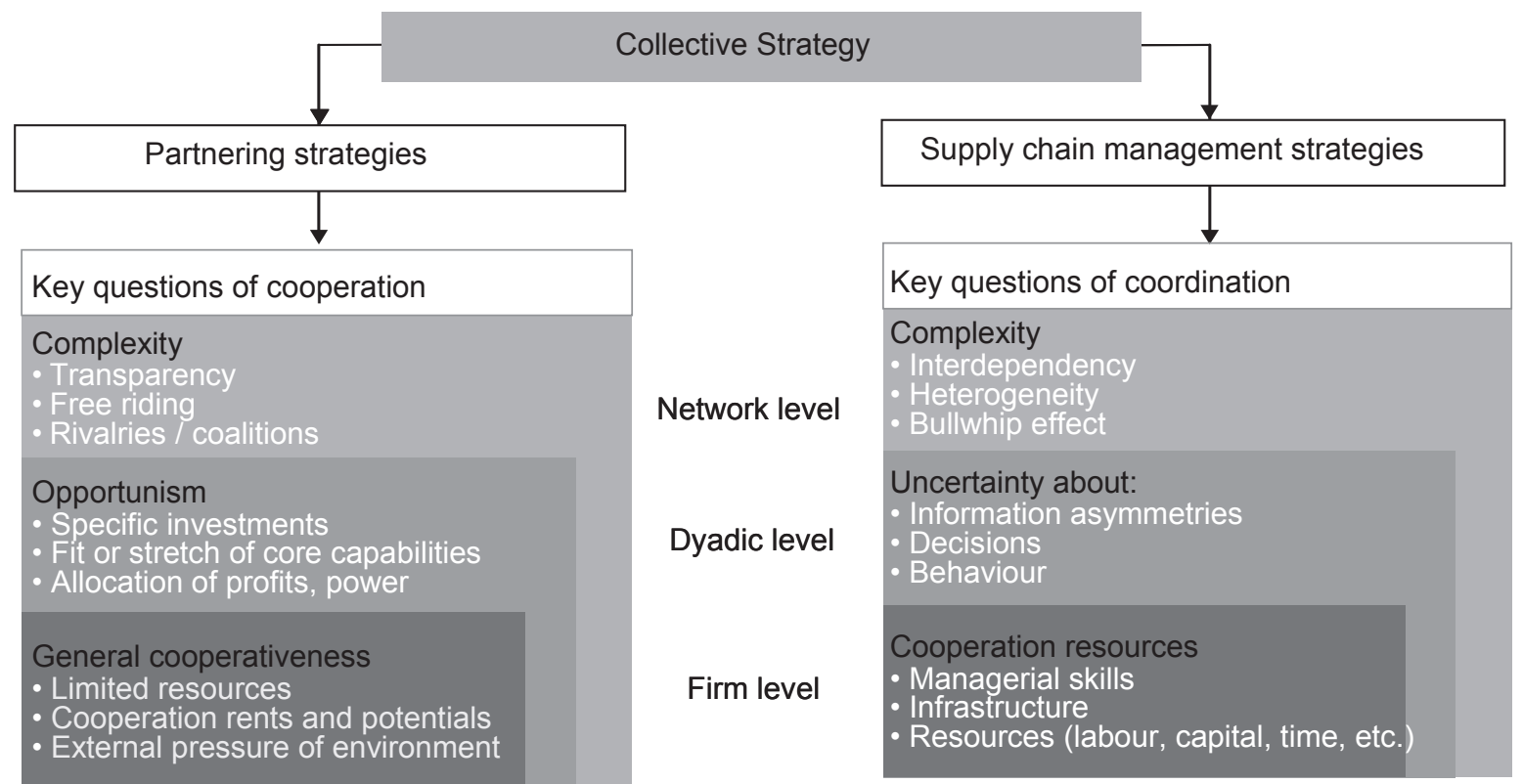

Figure 1. Concept of chain management.

as the ones to align the actions (coordination) must be simultaneously achieved.

Gulati (1998) emphasised that networks must be analysed not only from the perspective of the involved firms and the dyadic level of interaction, but also from the overall network perspective. However, particularly in the context of chain management, Duysters et al. (2004) have shown that collaborations must be analysed on three levels: the firm level, the dyadic level and the network level. We want to expand this concept by adding a distinction between cooperation and coordination. Opposing the tendency of economic theories to undervalue the role of people and their importance in the management of inter-organisational relations (Hutt et al., 2000), Granovetter (1985) argued that economic action is embedded in interpersonal social relationships. Thus, interpersonal relationships and individual positions always influence inter-organisational relationships and their outcomes (Lazzarini et al., 2001). With that in mind, we assume that there is a fourth level - a personal level. Because the possibility to communicate - to build trust and commitment between partners - is a basic requirement of collaboration, and because the personal level includes all social personal resources, it is closely connected with all three levels. However, because the requirements of the personal level are mostly important in the operative interaction between business partners and not so much in a strategic perspective, we will not discuss the personal level separately. Instead, we have integrated the main problems and mechanisms of personal relationships in the discussion of cooperation and coordination in light of the three levels.

\section{Mechanisms and instruments of cooperation and coordination}

\section{Cooperation and coordination on the network level}

\section{Network level}

Because most food is industrially produced, the food supply is sourced nationally or even globally. Supply chain networks consist of a multitude of participating firms along the food chain. Therefore, the embedded upstream and downstream flows of resources and information have to cross various stages of the chain. The firms involved differ greatly in size. As a result, supply chain networks are highly complex systems (Brito and Roseira, 2005; Goerzen and Beamish, 2005) with a high risk of failure. Thus, reducing complexity is one of the most important tasks in chain management (Ulaga and Eggert, 2006).

Firms believe that they can enhance their efficiency and their effectiveness by concentrating on fewer suppliers for their inputs and fewer channel members for distribution (Geyskens et al., 1998). For example, in the Japanese keiretsu the complexity of the supplier-buyer relationships is reduced by establishing system or key suppliers (Kim et al., 2004; Sydow, 1991). In this case, the focal company outsources the responsibility of key components to certain suppliers. These tier-one suppliers must set up their own supplier network. 
Nonetheless, the focal company still sets the overall rules, such as quality standards, and retains intervention rights. Even though network ties have a high risk of failure, they can also be regarded as a source of competitive advantages (Duysters and Heimeriks, 2002). Networks are flexible organisations. Therefore, dynamic capabilities such as integrating, building and reconfiguring internal and external competencies (Teece et al., 1997) can be seen as one of their competitive advantages. Network science consequently emphasises that collaboration is determined by the complementary abilities of the firms involved and by risk reduction (Menard, 2004; Menard and Klein, 2004). However, it is not only the fit and the combination of the resources of the single firms that create an advantageous position. The networks themselves can also be regarded as a source of unique and non-substitutable value (Gulati $e t$ al., 2000), thus expanding the traditional resource-based view (Barney, 1991).

Such resources can be grouped into two strands. Firstly, there are behavioural factors. Duysters and Heimeriks (2002:3) show that behavioural factors create relational advantages (Dyer and Singh, 1998) such as collaborationspecific rents (Madhok and Tallman, 1998), relational rents (Lane and Lubatkin, 1998), common benefits (Khanna et al., 1998) and relational capital (Kale et al., 2000). Secondly, structural factors also are important, such as networkspecific managerial mechanisms (Duysters and Heimeriks, 2002). By creating collaborative advantages (Dyer, 2000) or alliance capabilities (Kale and Singh, 1999; Kale et al., 2002), rent optimisation can be enhanced and firm-specific resources can be combined. Overall, such unique resources can be used to overcome the above-mentioned problems of cooperation and coordination (Gulati et al. 2005), so that collaboration can be used as a source of competitive advantage (Porter, 1980).

\section{Cooperation}

In general, problems in cooperation arise because selfinterested individuals optimise their own private benefits before they strive for collectively-beneficial outcomes (Gulati et al., 2005). Many authors have addressed this problem by using game theory, particularly focusing on the prisoner's dilemma and its varieties, such as the tragedy of the commons (Selten and Harsanyi, 1972). Gulati et al. (2005) conclude that the problem of cooperation can be regarded as one of motivation: which incentives can be used?

Formal and informal mechanisms that align the differing interests can be used to overcome these problems. Formal mechanisms are the following: contracting (Williamson, 1999), common ownership of assets (Grossman and Hart, 1986), monitoring and sanctions (Williamson, 1985), and the prospect of future interactions (Baker et al., 2002). Informal mechanisms to align interests are identification and embeddedness (Granovetter, 1985; Gulati, 1995; Kogut and Zander, 1996). Enhanced communication enables the participants to learn from and react to changes in the other partners' expectations. Therefore, it can be regarded as another informal mechanism, where ineffective communication causes conflicts, which results in improperly functioning relationships (Mohr and Nevin, 1990). Overall, trust can be seen as a prerequisite to gain the advantages of cooperation, because trust reduces the perception of risk associated with opportunistic behaviour, encourages effective communication and information sharing, and creates strong social bonds (Bleeke and Ernst, 1993, Mohr et al., 1996).

Due to the complex network nature of food supply chains, the structure is not made public to all network members, resulting in a feeling of anonymity. This lack of transparency in the network structure and affiliation increases the probability of free-riding. To solve this problem, networks must take measures to reduce anonymity and encourage identification with the network. They must also create incentives that align the interests of the single firm with those of the overall network (Zaheer and Bell, 2005). In the context of such norms, a common network culture, and a collective strategy are highly important. Additionally, studies at the network level emphasise the role of social capital (Inkpen and Tsang, 2005; Uzzi and Gillespie, 2002).

A distinction at the dyadic level is that coalitions are conceivable with more than two actors. Thus, through coalition building it is possible to facilitate interests which are not identical with network interests. Therefore, a powerful focal company must be allowed and be able to apply sanctions and fiats such as excluding network firms from the network (Brito and Roseira, 2005). Because networks consist of more than two enterprises, they can contain member firms which are also rivals. For example, various firms are needed on many stages of the supply chain to produce a certain quantity, so firms with similar competencies simultaneously collaborate and compete (Nalebuff and Brandenburger, 1996). To ensure that this rivalry does not lead to inefficiency, tasks must be clearly distributed with the intention of every network participant knowing what he has to do and why the other firms are needed. Whereas in a dyadic relationship the cooperation is terminated if the partners change or if one is dispersed in a network, single firms can be substituted and dispersed without the whole network being broken up (Goerzen and Beamish, 2005). To some extent, even the focal company could be substituted, as long as someone else can take over its functions. 


\section{Coordination}

Coordination can be considered to be the alignment of actions. Coordination problems therefore arise if actors are unaware that their actions are interdependent and if there is uncertainty about the rationality of others, creating doubt about how the others will act (Gulati et al., 2005). Thus, coordination problems also arise when the partners fail to share accurate knowledge about the decision rules that others are likely to use and how their own actions interact with those of the others (Gulati et al., 2005: 419). Formal mechanisms for overcoming coordination problems are programming, hierarchy and feedback, along with culture, commitment and a collective strategy (Kogut and Zander, 1996; March and Simon, 1958; Nadler and Trushman, 1998; Thompson 1967). For example, schedules and standards are implemented to enhance the predictability of the others' actions. Such ex ante agreements can be regarded as programming.

A better way of enhancing predictability is to introduce hierarchal elements such as single sources of authority and centralised decision making (Thompson, 1967). These mechanisms are particularly helpful for overcoming problems that stem from pooled and reciprocal interdependencies. For pooled interdependencies, the optimal status can be created if each task is performed independently (Gulati et al., 2005: 423). The creation of standards can be helpful for the management of pooled resources. Thompson (1967: 54) characterised reciprocal interdependencies as those which evolve because they demand "ongoing communication to create awareness about one other's action".

In a procurement relationship, reciprocal interdependencies also arise if the production or the design of a product requires the intensive interaction of the buyer and the supplier. Reciprocal interdependencies generally require additional mutual trust to overcome their restraints (Gulati, 1995).

Cooperation problems evolving from free-riding occur in reciprocal interdependencies. Because there is a connection between trust, commitment and enhanced communication, it is evident that communication is extremely important in managing reciprocal interdependencies (Mohr and Nevin, 1990). Building routines can also be regarded as a coordination mechanism. Additionally, as evolutionary economics show, knowledge assets are embedded in routines (Nelson and Winter, 1982). Moreover, the networks' ability to establish learning routines can be viewed as a further mechanism to develop unique and network-specific knowledge, creating a further inimitable and non-substitutable collaboration advantage (Dyer and Hatch, 2006; McEvily and Marcus, 2005).
The complexity of network structures plays an important role in coordination at the network level. The more actors that are involved in a network, the higher the number of both interactions and interdependencies. Because the increase of interdependencies is disproportional, the coordination tasks are extremely difficult. As time goes on, network performance is not only related to current ties, but also to ties with potential partners. This is important for two reasons: bridging structural holes and ensuring the efficiency of the network (Zaheer and Bell, 2005). For these tasks, it is necessary to evaluate current members and their resources and capabilities.

The approach of network marketing indicates that through senior managers' personal relationships, the firms' position in the network can be developed so that the interaction of sellers, buyers and other parties can be mutually beneficial (Lindgreen et al., 2005). Furthermore, the great deal of required coordination between the partners demands efficient coordination mechanisms such as management concepts known from organisation science (Bogaschewsky, 1995). However, the need for and the explicit knowledge of firm strategies, culture and values differ with the firm size. For example, the strategic management of farmers differs significantly from that of retailers or large manufacturers. Therefore these differences must be considered during the conceptualisation of shared chain management. The creation of a collective strategy, along with a common chain culture and shared values and norms, facilitates the alignment of the network participants.

Another important topic is the usage of modern information technology (IT) and infrastructure (Fritz and Schiefer, 2002; Müller, 2001). Supply chain networks in the agrifood business quite often consist of heterogeneous firms; therefore the IT infrastructure of the individual network firms differs. Consequently, a common IT infrastructure, or at least a compatible IT system, must be attained. In the case of small and medium-sized firms, especially farmers, such investments in IT infrastructure can often be regarded as specific investments. As a result, mechanisms such as the exchange of hostages or shared investments (Sydow, 1991) have to be installed to demonstrate that the other network firms will not behave opportunistically.

Due to this information problem, studies at the network level emphasise the role of social capital to enhance and bring about information exchange that results in information advantages (Uzzi and Gillespie, 2002). Not sharing information along the whole supply chain causes a build up of supplies - unnecessary stocks - which is characterised as the bullwhip effect (Haehling von Lanzenauer and Pilz-Glombik, 2000; Lee et al., 1997). This problem can be solved by softening the information barriers so that critical and sensitive information such as scanner 
data and the amount of stocks can be passed throughout the chain (Alvardo and Kotzab, 2001; Müller et al. 2003; Obersojer and Weindlmaier, 2006).

In summary, our discussion on the network level highlights the importance of the network's complexity in the design of the partnering strategy as well as the supply chain management strategy.

\section{Cooperation and coordination on the dyadic level}

\section{Dyadic level}

Analyses at the dyadic level reveal which characteristics and restraints a collaboration of only two firms has. Although it has been some years since the theory of new institutional economics (NIE) has been applied to collaborations exceeding two players, traditionally NIE - especially transaction cost economics (TCE) - has been used on the dyadic level (Carter and Hodgson, 2006; David and Han, 2004). Therefore, we will take a closer look at these theories on this level. Although we will pay special attention to NIE/TCE, which both emphasise mechanisms to overcome hazards of opportunistic behaviour as well as the potential to significantly reduce transaction costs, we want to remind the reader that the advantages resulting from collaboration that we discussed above are also very important to the explanation of dyadic partnerships (Arend, 2006, White and Siu-Yun Lui, 2005).

\section{Cooperation}

Because cooperation involves two independent enterprises, its key problem is that each firm has different motives, reasons and preconditions for joining the collaboration which might lead to opportunistic behaviour, such as the potential for hold-up in vertical relationships (Shelanski and Klein, 1995). Thus, the canonical problem of cooperation is the alignment of the involved firms' interests (Gulati et al., 2005). For example, in today's procurement relationships, more and more specific investments must be made. Such investments create the opportunity for the other party to renegotiate the terms of the deal (David and Han, 2004). In this case of opportunistic behaviour, the "shadow of future interactions" can align the interests (Dal Bo, 2005; Heide and Miner, 1992). This means that the prospect of future gains and advantages resulting from the collaboration prevents one side from cheating the other, which can be shown by applying game theory to open-end games (Fudenberg and Tirole, 1991).

Generally speaking, it is feasible to establish common ownership, incentives, sanctions and monitoring mechanisms to overcome these kinds of problems (Williamson, 1975; Grossman and Hart, 1986; Baker et al. 2002). It has been observed that rather formal mechanisms often are used at the beginning of collaboration, whereas over time more and more informal mechanisms are substituted for the formal ones (Gulati, 1995). A more informal mechanism is the creation of a common identity so that the individual players identify themselves with the collaboration (Kogut and Zander, 1996). Embeddedness also acts as an informal mechanism (Granovetter, 1985). Another appropriate mechanism for preventing opportunistic behaviour is building trust (McEvily and Marcus, 2005). Having trust also means that a firm can have confidence in the information which is transmitted by its collaborating counterpart (Das and Teng, 1998). Thus, one manner of creating trust is to enhance communication. Communication is the process by which persuasive information is transmitted in relationships, participative decision-making is fostered, power is exercised and commitment and loyalty are encouraged (Mohr and Nevin, 1990).

Communication is a trust-forming mechanism, but inadequate communication can also be a restraint to cooperation. If the collaborating firms are unable to communicate properly, conflicts arise (Bleeke and Ernst, 1993, Mohr et al., 1996). Empirical studies on business-tobusiness partnership formation show that enhanced and accurate communication is one of the most important determinants for successful partnerships (Tuten and Urban, 2001). Because information is generally exchanged by people on an operational level, on the dyadic level the social and personal relationships of the people involved are also very important. Thus, on a dyadic level as well as on a network level, an important managerial task is ensuring that the involved people match each other (Kale et al. 2002). Another important point is that the core competencies and resources of the involved firms fit each other so that there is an additional rent from the cooperation (Dyer and Hatch, 2006; Williamson, 1999). Examples of sources of such relational rents can be found in bargaining power due to collusions, scarce tangible and intangible assets, interfirm knowledge sharing routines and complementary resource endowments (Dyer and Singh, 1998). Dyer and Singh (1998:674) list mechanisms to preserve these rents. They include industry barriers to entry such as government regulations, firm-level barriers to imitation such as resource scarcity or property rights, causal ambiguity and time compression diseconomies, along with dyadic barriers to imitation such as causal ambiguity, inter-organisational asset interconnectedness and partner scarcity.

However, it is still unclear how these relational rents are shared between the involved parties. This rent can not only be used as an incentive to collaborate, but if the mode of allocation is unclear, it also acts as a source of discontentedness or even opportunism. A mechanism 
for overcoming this problem is to implement strict rules regarding how to share the rent and/or how to evaluate the inputs of each participant. Hence, the firm which brings more critical resources into the collaboration will get a higher percentage of the rents (Dyer, 1996; Pfeffer and Salancik, 1978).

Next, the question of power arises. Power can be distributed equally or unequally. Nevertheless, as long as it is clear who carries the responsibility and the decision rights for a certain task, and as long as the partners accept the power distribution, we assume that the power distribution itself is not a problem. However, if it is unclear or a partner does not accept the distribution, opportunistic behaviour arises. Moreover, if a partner perceives inequity, their willingness to continue the alliance or to continue to invest in the collaboration decreases, seriously affecting its outcome (White and Siu-Yun Lui, 2005). Clear governance structures are therefore necessary. The optimal form of governance is the result of the attributes of the current transaction and the pre-existing strengths and weaknesses of the focal firm (Leiblein and Miller, 2003).

\section{Coordination}

Independent single firms interact with each other at the dyadic level. Because these actions demand that firms coordinate their movements, as mentioned above, the general coordination problem can be characterised as a lack of knowledge about how the other party behaves and uncertainty about which decision-making rules will be applied (Gulati et al., 2005). Integrating feedback processes and improving communication between the partners helps to enable mutual adjustment on an ongoing basis (Mohr et al., 1996).

In addition to the formal mechanisms, informal mechanisms can be used to overcome the constraints of coordination. Such mechanisms are leadership, norms, culture, shared values and commitment, trustworthiness and a shared strategy (Hanf and Kühl, 2005). When two firms interact, interdependencies (sequential, pooled and reciprocal) also arise (Theuvsen, 2004). Sequential interdependencies are particularly important at the dyadic level. In the agri-food business, the demand (including consumer demand) and supply of commodities are very unstable. Consequently, sequential interdependencies must be analysed in the context of an unstable environment. In this case, continuous communication and planning adjustments are necessary (Mohr et al., 1996).

Furthermore, with respect to managerial discretion, the role of communication for sequential interdependency can be described as providing an optimal flow of technical and operative information throughout the whole SCN so that information asymmetries can be reduced (Bleeke and
Ernst, 1993). Communication, like trust and commitment, also requires people interacting on the dyadic level to ensure that there is continuity in the interacting people. In business practice, for example, key account managers are appointed to ensure that the same face is always presented to the customer over the long term. This shows that repeated interactions justify the creation of structural mechanisms of coordination. Thus, collaborations benefit from coordination mechanisms which are not available in arm-length transactions (Gulati and Singh, 1998).

Zaheer and Vatakatraman (1994) illustrate how information technology and inter-organisational structures are enhancing the coordination efforts. Additionally, the formation of interfirm routines can be regarded as a source of superior capacity for coordinating (Dyer and Singh, 1998; Gulati $e t$ al., 2005). In addition, inter-organisational routines as well as experiences of observation and demonstration can be regarded as a source of knowledge creation (Hamel, 1991; Kale et al., 2002; McEvily and Marcus, 2005). During the course of the "IT Revolution" in the 1990s, it was important for coordination issues at the dyadic level that the rather intrafirm orientation of the concept "business logistics" had been altered to an interfirm perspective (Otto/Kotzab 2001). This development was also catalysed by the fact that Anglo-American consultancies established supply chain management tools optimising the product, work, information and monetary flows between suppliers and buyers (Seifert, 2004; Werner 2000).

Supply chain management (SCM) can be understood as the room for improvement at the interfaces of different functions or processes in the enterprises and between enterprises (Lee 2004). Thus, SCM aims to optimise logistics, reduce stocks, adjust plans and enhance information exchange (Gunasekaran and Ngai, 2005; Hoffmann and Mehra, 2000; Kotzab 1999; Otto and Kotzab, 2001). The concept of efficient consumer response (ECR) was introduced because a very important success factor of SCM is the optimisation of the interfaces between the supplier and buyer. To avoid any out-of-stock situation, all relevant scanner data is automatically transmitted to the supplier. The supplier assures that if the stocks reach a minimum level they will refill them without the order of the retailer (Mau, 2000, Werner, 2000). Losses are minimised by building cross docking stations and synchronising the production time (Mau, 2000).

Besides the alignment of actions of the supply side, ECR also aims to match the actions of the demand side, which is also called category management (Seifert, 2004; Sharma and Levy, 1995; Zenor 1994). It comprises three components: efficient product introduction, efficient store assortment and efficient store promotion (Mau, 2000; Mulhern et al., 1995; Vilcassim and Chintagunta, 1995). Since the late 1990s, 
when the importance of a joint forecast was recognised, the concept Collaborative Planning Forecasting and Replenishment (CPFR) has emerged (Seifert, 2004). Again, this concept tries to further ameliorate the coordination between the partners in the supply chain. By using modern IT solutions, CPFR aims to optimise a common forecast (Thome et al., 2004). Overall, these chain management concepts that are used in business today mainly address coordination problems with more of an operative nature than a strategic one.

Our analysis of the dyadic level shows that opportunism is the key issue that must be dealt with by the partnering strategy. The supply chain management strategy comprises all the mechanisms addressing the reduction of uncertainty.

\section{Cooperation and coordination on the firm level}

\section{Firm level}

Although research on networks focuses on the interrelationships between firms, single enterprises can be regarded as the initial elements. Without them, collaborations do not exist. Therefore, the analysis of the firm level aims to find reasons, problems and solution mechanisms for single network firms that evolve in the context of the network (Duysters et al., 2004). Firms must be aware of the existence of potential partners, and they need information about the reliability of those partners (Balakrishnan and Koza, 1993). Moreover, at the firm level it must be determined that the firms` strategy is in line overall with the collective strategy (Bresser, 1988), creating a strategic fit.

Besides the strategic fit, there also has to be an organisational fit between the partnering enterprises (White and SiuYun Lui, 2005). Thus, the preparation of appropriate firm structures is another task on the firm level. Since the exchange between the firms in networks is administrated and exercised by employees, the general challenge for the companies is to install mechanisms to transform the skills, contacts and knowledge from the personal level to the firm level. In general, mechanisms to overcome these intra-firm conflicts can be found in the intra-organisational management literature (Blake et al. 1964; Bleicher, 1991; Bühner 1990; Kirsch 1990; Macharzina, 2004; March and Simon, 1958; Müller-Stewens and Lechner, 2001; Thompson 1967).

Such mechanisms work in such a way that if an employee leaves the company, the knowledge and skills acquired on the personal level stay within the enterprise. In the context of network management, on the firm level additional specific managerial capabilities are very important. Because firms often participate in many collaborative partnerships, not just one network, such skills aim to provide the intrafirm structural mechanisms to manage the alliance portfolio (Reuer and Ragozzino, 2006). Because the firms involved in a food supply chain network are very heterogeneous, the mechanisms used can differ widely. Whereas large enterprises may install special units or managers which are solely responsible for managing the alliance portfolios (Ethiraj et al., 2005; Kale et al., 2002; Duysters and Heimeriks, 2002), in small firms, such as farms, the owner himself has to manage the network affairs.

\section{Cooperation}

Although it may sound self-evident or trivial on this level, we believe the essential prerequisite is the willingness of both the firms and the people involved to cooperate. Collaborations do not always create advantages for the firms involved, but they also absorb resources - especially during their establishment. Therefore, without general cooperativeness we can assume that the collaboration will fail. Because cooperation demands that enterprises adjust their own actions to the actions of their partners, on the firm level general cooperativeness means that the enterprises must be willing to relinquish some of their managerial freedom. Thus, firms have to recognise collaborations as a means to overcome limitations of their resources.

Furthermore, firms have to understand cooperation as a lever that increases their own profits. Networks are not simply unique bundles of resources (Gulati et al., 2000); cooperation rents also arise from resource complementarities (Lane and Lubatkin, 1998; Khanna et al., 1998). However, created value is not only constrained by knowledge of resource complementarities, but also by transaction costs that accompany the exchange (Foss and Foss, 2005). Overall, firms must understand cooperation as a unique source for pursuing strategic objectives by achieving cooperation benefits and efficiency gains (Echols and Tsai, 2005; White and Siu-Yun Lui, 2005; Zaheer and Bell, 2005).

Additionally, market forces and political pressure both act as enablers of cooperation. For example, for agricultural entrepreneurs an essential factor driving their willingness to cooperate is based on external pressure, such as the intrasectoral frictions of structural change and subsidy reductions as well as the possibility of market entrance (Balmann et al., 2006). However, not only the willingness to cooperate with other firms is essential, but the willingness to cooperate within the company also has to be ascertained. Thus, on the firm level a key issue is the involvement of top management in the cooperation or the establishment of a special organisational function which is responsible for cooperation management (Kale et al., 2002).

Another important point is to ensure that the staffs of the various business units are collaborating with each other and that they are willing to collaborate with their 
counterparts from the partnering firm. Mechanisms derived from the NIE - in particular from the principalagent approach such as implementation of incentives schemes, monitoring mechanisms or agent tenure - can be regarded as an adequate mechanism (Arthur, 1994; Bloom and Milkovich, 1998; Holmstrom, 1982; Shaw et al., 2000; Stroh et al., 1996). Furthermore, interaction marketing indicates that combining business meetings and social get-togethers creates a close and trustful relationship between the individuals, thus facilitating mutual benefits (Lindgreen et al., 2005).

Because these networks are designed to last over a long period, general cooperativeness is not only essential at the beginning of the cooperation, but throughout. Thus, as long as the advantages of the cooperation outweigh its costs, we expect that there will be a willingness to cooperate. Therefore, firms must continuously evaluate cooperation. Such an evaluation must be based on a continuous analysis of the firms' strengths and weaknesses, as well as the opportunities for and threats to the firms.

\section{Coordination}

If a firm is participating in a network, it will have additional tasks and added work. Collaboration consumes resources of the firms in the network. This results, for example, in time restraints for the managers and reallocation of employees. Therefore, managing collaboration at the firm level demands specific managerial skills as well as resources (Duysters and Heimeriks, 2002; Dyer and Singh, 1998; Kale et al., 2002; Zaheer and Bell, 2005). Kale et al. (2002:750) observed that successful alliances establish dedicated alliance posts such as "Vice President or Director of Strategic Alliances", where staff and resources specifically coordinate all the alliance-related activities of the firm. The creation of such an organisational unit has the advantage that knowledge creation is fostered. Because knowledge assets are embedded in firm routines (Nelson and Winter, 1982), they can be regarded as the basis of firm capabilities (Dyer and Singh, 1998). Therefore, firms can only gain knowledge from their network ties after they successfully implement a new set of routines (Dyer and Hatch, 2006). Holding regular meetings with the partnering firms or creating joint training programmes are examples of such routines (Dyer and Nobeoka, 2000).

In addition to the knowledge aspect, the creation of specialised organisation structures helps to accumulate and combine experience so that it can be transferred easily to new situations (Duysters and Heimeriks, 2002). Furthermore, Duysters and Heimeriks argue that having a dedicated unit of alliance management facilitates the identification of needed resources as well as the dissemination of the acquired ones. Thus, on the firm level it is essential to have a clear strategic objective about what can be gained from the partnership (Hamel et al., 1989). Such a dedicated alliance function has also the task of identifying possible partners; at most, firms can only access the resources that are available from their chosen alters (Gulati, 1999, Stuart, 2000).

Tools are needed to achieve this task. For example, analyses at the firm level reveal that successful cooperation employs a significant number of managerial constructs known from single firms such as alliance databases, joint business planning and alliance managers (Duysters et al., 2004). Overall, such tools support the dedicated alliance functions by disseminating knowledge through codification or verbalisation (Duysters and Heimeriks, 2002). Because agrifood firms in supply chain networks are very heterogeneous, quite often they do not have the magnitude to create a whole new organisational unit. Nevertheless, regardless of the size of a firm, we believe that sufficient organisational and managerial resources must be provided on the firm level. Additionally, the degree of management professionalism between the single firms varies. Specifically on the agricultural level, which is dominated by family farmers, we therefore assume that time restraints and managerial constraints must both be addressed. In this context, we presume that managerial constraints can be reduced by continuously broadening education, as well as participating in regular in-house training.

In conclusion, it can be assumed that the general cooperativeness of the firms is a central variable for cooperation and therewith for the overall partnering strategy on the firm level. Resources and capabilities needed on the firm level are the key issues for the supply chain management strategy or the coordination part of the chain management concept.

\section{Visualisation of the concept}

We conducted interviews to analyse a food supply chain network producing premium pasta to work out key assumptions of the chain management concept. The network structure is as follows: the pasta manufacturer itself, a mill, a logistics provider and a producer co-op consisting of twenty farmers (Figure 2). The focal company is the branded, medium-sized pasta manufacturer that guarantees the quality and credence attributes to the consumers. Therefore, the pasta manufacturer assumes not only the responsibility for the final pasta product, but also for the whole production process. To fulfil this obligation, the manufacturer has chosen a key supplier who must guarantee the quality of the entire production process. Additionally, the focal firm sets general quality requirements, standards and specifications. The producer co-op performs the function of the key supplier by organising the horizontal cooperation of the twenty farms, as well as the relations 


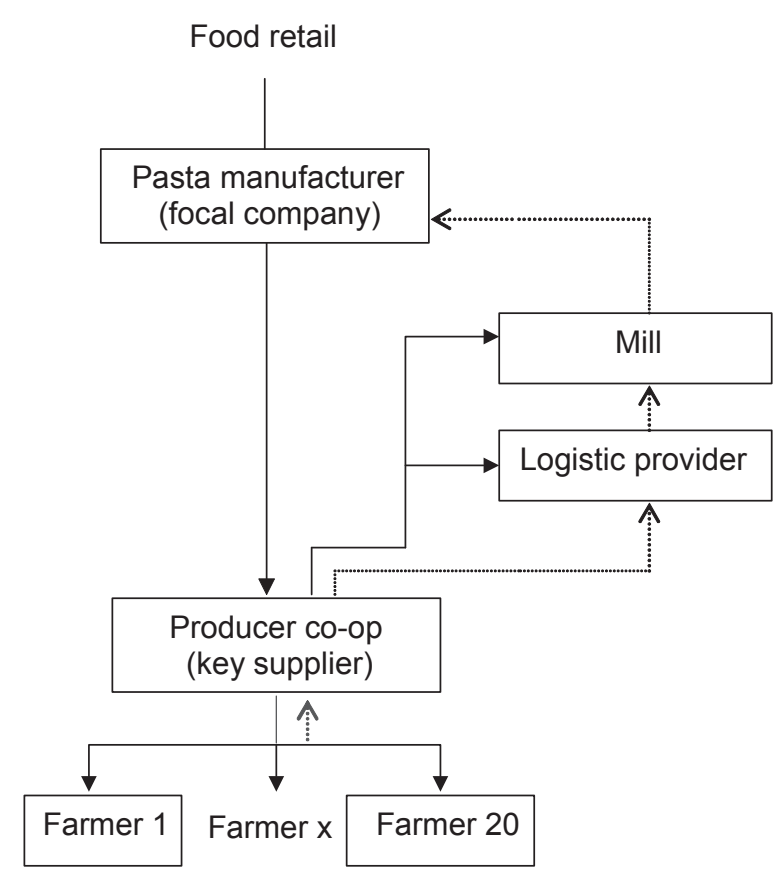

Figure 2. Case of a supply chain network.

between the mill and the logistic suppliers that specialise in transporting agricultural products.

In general, the collective strategy is the starting point of the chain management concept. In this case, the collective strategy of the whole network is a quality strategy, initialised by the pasta producer. The next step of the chain management concept is defining the partnering and supply chain management strategies, i.e. how do the focal company and the key supplier manage the supply chain network with respect to behavioural factors and structural factors?

Reducing complexity is a major issue because cooperation problems can be regarded as a problem of motivation on the network level. Thus, it is essential to use a key supplier. This was possible because the agricultural enterprises are organised as a producer co-op. Furthermore, the farmers felt confident that the other farmers would not behave opportunistically because they all shared ownership of the cooperative. To further overcome cooperation problems and create trust, the pasta producer and the co-op initiated annual meetings of all the involved firms. As a result, the network loses anonymity; the network structure becomes more transparent, thus avoiding the prospect of free-riding. Another important aspect of the annual meeting is that all participants get to know each other on a personal level. Moreover, the farmers do not compete for new contracts when they become aware that they need each other to deliver the demanded quantity. In this way, mechanisms such as definition of common values, permanent feedback and clarification of tasks and resources are specified on the network level, which helps to achieve transparency between partners.

The main findings on the coordination issues on the network level are derived directly from the collective strategy of quality leadership. Pooled interdependencies are addressed because the focal company requires compliance with defined quality standards. They are based on specific and common agricultural practices, joint marketing, exchange of experience and the shared acquisition and use of production factors and storage. All these standards are codified in a quality manual.

Quality strategy specifies that arrangements are made to meet or exceed quality standards such as traceability requirements, crop rotation, variety choice, seed and sowings, fertilisation, pesticide management, irrigation and harvest methods. Because the production of high quality durum wheat requires the use of modern farm equipment compatible with GPS systems, the IT infrastructure of the whole supply chain network was synchronised. Again, the aforementioned trust-building mechanisms have been crucial to obtaining these specific investments.

On the dyadic level, the fundamental requirement for cooperation is that the focal company only chooses firms which have clearly indicated that they are willing to cooperate and are capable of doing so. Whereas the focal firm pursues the strategy of quality leadership, the producer co-op follows diversification and niche strategies. The common aim of all agricultural enterprises is to reduce marketing risk and optimise time management, due to the different harvest time for durum wheat compared to other crops.

However, the twenty farms, with an average size of 2,000 hectares, have the common intention of producing and marketing high quality durum wheat with traceable quality attributes. Thus, there is a strategic fit between all involved firms. Additionally, the quality standards are continuously certified by an independent controller who is paid by the coop. This is considered an investment in human capital and a signal to exclude hidden characteristic behaviour. A price premium is paid to the agricultural enterprises and viewed as an additional incentive. In accordance with the network level, issues related to coordination quality are also very important. The quality manual allows managerial discretion and addresses the sequential interdependencies. Getting to know each other in the annual meetings helps overcome uncertainty about the others' decisions and reduces the information asymmetries and communication problems. In this way, reciprocal interdependencies can be managed.

The agricultural entrepreneurs are severely affected by the external pressures of structural change and subsidy reductions, such as direct payments or the current debate 
about voluntary modulation after 2008. As a result, they have a general willingness to cooperate. For the premium pasta producer, the advantages of cooperation on the firm level arise from quality guaranties, close feedback to producers and partial independence from the market. Managerial skills must be developed to coordinate the cooperation on firm level. The objective on the operative level is a standardisation of the manufacturing process for quality assurance and traceability via documentation. This requires all mangers on the firm level to participate in training seminars (in-house) and continuing education.

\section{Conclusion}

\section{Limitations and directions for future research}

In this paper we have attempted to outline a chain management concept. Our study, like any study, suffers from limitations. First, it is based on a single sector with its own particular characteristics. Thus, we were unable to generalise the substantive results of this paper to other industries. Because the conceptualisation is based on network theories and related managerial approaches, we assume that the above-mentioned restraint is alleviated.

However, this leads to the second limitation. Our paper is based on an extensive literature study, but there is still a problem about covering all articles. Although we tried to cover the huge number of relevant articles, we were unable to work through all of them. We are fully aware that we may have missed some relevant work, but we made every effort to minimise that risk.

The third limitation of our paper concerns to the visualisation of our concept. Because we only analysed one supply chain network, we decided that we cannot use it as a case study validation. However, since the results of the conducted interviews have been in line with our theoretical approach, we decided to use it as an example.

Despite these limitations, our work is part of the strand of alliance capability research. We also aimed to combine the theoretical knowledge on chain management so that we could build a comprehensive, but feasible, concept. This concept provides a holistic view of chain management and therefore offers new insights for academics and practitioners alike.

On the firm level, we therefore hope we can help answer Williamson's (1999:1103) question, "How should a firm $\mathrm{A}$, which has pre-existing strength and weaknesses (core competencies and disabilities), organise X?". We also wanted to show that cooperation is more than just reducing transaction costs, that it also offers a unique source for creating value (Zajac and Olsen, 1993).
It is in this vein that we see a major contribution of our work to the strand of alliance or network capabilities. We hope to make a contribution by answering the question, "there is a thing called an alliance competence, and where it might reside in the organization?" Zajac (1998:320). Drawing on the works of Gulati et al. (2005) and that of Duysters et al. (2004), we were able to show that network management, as a unique source of competitive advantage, must include cooperation and coordination as two sides of a coin, and at the same time it must take the three network levels into account.

Generally speaking, future research is needed to empirically verify chain management concepts. We want to encourage the use of case studies to acquire more insight into the "real" world of supply chain networks. In particular, long-term case studies with large samples are required. Both qualitative and quantitative approaches must be applied. Because chain management concepts are based on the combination of managerial constructs, we consider the application of structural equation modelling and path analysis to be useful methods.

\section{Managerial implications}

Understanding the various determinants of chain management is the most important managerial issue for every supply chain network. Our concept provides several important implications for this practice. In broad terms, it highlights the strategic value of viewing chain management as a multifaceted construct consisting of cooperation and coordination elements on the various network levels. In particular, existing concepts such as supply chain management are focused on coordination matters such as optimising logistics (Müller et al., 2003; Otto and Kotzab, 2001). By focusing on coordination issues, cooperation is regarded as a necessity. However, it is not specifically addressed, which results in high failure rates and dissatisfaction.

In addition, this balanced approach to cooperation and coordination introduces the three network levels that create a holistic view of chain management. This helps the involved firms, especially the focal company, to acquire foresight about which problems are most relevant on each level and thereof to reduce conflicts. However, because our concept must be regarded as a pattern and not as a straightjacket, it also must be considered as an analytical tool for designing strategic chain management. The strategic usage of such a unique relational capability should provide the networks with a competitive advantage. Moreover, by applying our concept, networks will foster the creation of both a strategic fit and an organisational fit on all three network levels. 


\section{Summary}

When perusing the relevant literature on chain management, it becomes evident that the majority of articles addressing this topic focus on one of two issues: how to facilitate cooperative behaviour, and thereby cooperation, or how to coordinate the business processes between the interacting partners. However, the combination of both aspects is seldom addressed. Therefore, the framework of chain management that we have developed combines the aspects of cooperation and coordination - i.e. the collective strategies of partnering and supply chain management with the firm, dyadic and network levels.

Furthermore, on each level our framework includes mechanisms to overcome the problems arising from cooperation and coordination. Key questions regarding cooperation address the general cooperativeness of the single firms on the firm level, opportunism on the dyadic level and the complex structure of networks on the network level. Key questions concerning coordination deal with the general ability of the single firms to participate in the collaboration on the firm level, the uncertainty about the others' decisions and behaviour on the dyadic level and the complexity of the interactions of several firms on the network level. The practicability of our concept was visualised in the supply chain network of a German premium pasta manufacturer. This showed that the combination of cooperation and coordination with a differentiated view of the various network levels corresponds with the demands of real business life.

\section{Acknowledgement}

First of all we would like to thank both anonymous reviewers for proving such helpful commands and suggestions. Secondly, we want to thank our interviewees for spending so much time with us. Also we want to thank the IAMO for providing financial support for conducting the interviews.

\section{References}

Alvarado, U.Y. and H. Kotzab, 2001. Supply Chain Management: The Integration of Logistics in Marketing. Industrial Marketing Management, Vol. 30, 183-198.

Arend, R., 2006. SME-supplier alliance activity in manufacturing: contingent benefits and perceptions. Strategic Management Journal, Vol. 27, 741-763.

Arthur, J.B., 1994. Effects of human resource systems on manufacturing performance and turnover. Academy of Management Journal, Vol. 37, 670-687.
Astley, W.G. and C.J. Fombrun, 1983. Collective Strategy: Social Ecology of Organizational Environments. Academy of Management Review, Vol. 8, 576-587.

Astley, W.G., 1984. Towards an Appreciation of Collective Strategy. Academy of Management Review, Vol. 9, 526-535.

Baker, G., R. Gibbons and K.J. Murphy, 2002. Relational contracts and the theory of the firm. Quarterly Journal of Economics. Vol. 117, 39-84.

Balakrishnan, S. and M.P. Koza, 1993. Information asymmetry, adverse selection and joint ventures: Theory and evidence, Journal of Economic Behavior and Organization, 20, 99-117.

Balmann, A., K. Dautzenberg, K. Happe and K. Kellermann, 2006. On the dynamics of structural change in agriculture - Internal frictions, policy threats and vertical integration, Outlook on Agriculture, Vol. 35, 115-121.

Barney, J., 1991. Firm Resources and Sustained Competitive Advantages. Journal of Management, Vol. 17, 99-120.

Bleicher, K., 1991. Das Konzept Integriertes Management. CampusVerlag, Frankfurt, Germany.

Blake, R.R, H.A. Shepard and J.S. Mouton, 1964. Managing intergroup conflicts in industry. Gulf Pub. Co., Houston, USA.

Bleeke, J. and D. Ernst, 1993. Collaborating to Compete. John Wiley \& Sons, NY.

Bloom, M. and G. Milkovich, 1998. Relationships among risk, incentive pay and organizational performance. Academy of Management Journal, Vol. 41, 283-298.

Boehlje, M., 1999. Structural changes in the agricultural industries: how do we measure, analyze and understand them? American Journal of Agricultural Economics, Vol. 81, No 5, 1028-1041.

Bogaschewsky, R., 1995. Vertikale Kooperation - Erklärungsansätze der Transaktionskostentheorie und des Beziehungsmarketings. Zeitschrift für betriebswirtschaftliche Forschung, Sonderheft 35, 159-178.

Bresser, R.K.F. and J.E. Harl, 1986. Collective Strategy: Vice or Virtue? Academy of Management Review, Vol. 11, 408-427.

Bresser, R.K.F., 1988. Matching collective and competitive strategies. Strategic Management Journal, Vol. 9, 375-385.

Brito, C. and C. Roseira, 2005. A model for understanding supply chain networks. Journal on Chain and Network Science, Vol. 5, 55-63.

Bühner, R., 1999. Das Management-Wert-Konzept. Schäffer Verlag, Stuttgart, Germany.

Burr, B., 1999. Koordination durch Regeln in selbstorganisierenden Unternehmensnetzwerken. Zeitschrift für Betriebswirtschaft, Vol. 69, 1159-1179.

Carney, M.G., 1987. The Strategy and Structure of Collective Action. Organization Studies, Vol. 8, 341-362.

Carter, R. and G.M. Hodgson, 2006. The Impact of empirical tests of transaction cost economics on the debate on the nature of the firm. Strategic Management Journal, Vol. 27, 461-476. 
Dal Bo, P., 2005. Cooperation under the shadow of the future: Experimental evidence from infinitely repeated games. The American Economic Review, Vol. 95, 1591-1604.

Das, T.K. and B.-S. Teng, 1998. Between trust and control: Developing confidence in partner cooperation in alliances. Academy of Management Review, Vol. 23, 491-512.

David, R.J. and S.-K. Han, 2004. A systematic assessment of empirical support for transaction cost economics. Strategic Management Journal, Vol. 25, 39-58.

Duysters, G.M. and K.H. Heimeriks, 2002. Alliance capabilities How can firms improve their alliance performance? Paper at the 6. International Conference on Competence-based Management, IMD, Lausanne, Switzerland.

Duysters, G.M., K.H. Heimeriks and J.A. Jurriens, 2004. An integrated perspective on alliance management. Journal on Chain and Network Science, Vol. 4, 83-94.

Dyer, J.H., 1996. Specialized supplier networks as a source of competitive advantage: Evidence from the auto industry. Strategic Management Journal, Vol. 17, 55-83.

Dyer, J.H. and H. Singh, 1998. The relational view: cooperative strategy and sources of interorganizational competitive advantages. Academy of Management Review, Vol. 23, 660679.

Dyer, J.H. 2000. Collaborative Advantage. Winning through extended enterprise supplier networks. Oxford University Press, New York.

Dyer, J.H. and K. Nobeoka, 2000. Creating and managing a high performance knowledge-sharing network: The Toyota case. Strategic Management Journal, Special Issue, Vol. 21, 345-367.

Dyer, J.H. and N.W. Hatch, 2006. Relation-specific capabilities and barriers to knowledge transfers: creating advantages through network relationships. Strategic Management Journal, Vol. 27, 701-719.

Echols, A. and W. Tsai, 2005. Niche and performance: The moderating role of network embeddedness. Strategic Management Journal, Vol. 26, 219-238.

Ethiraj, S.K., P. Kale, M.S. Kirshnan and J.S. Singh, 2005. Where do capabilities come from and how do they matter? A study in the software services industry. Strategic Management Journal, Vol. 26, 25-45.

Foss, K. and N.J. Foss, 2005. Resources and transaction costs: How property rights economics furthers the resource-based view. Strategic Management Journal, Vol. 26, 541-553.

Fritz, M. and G. Schiefer, 2002. Market monitoring in dynamic supply chain networks and chains: an Internet-based support system for the agri-food sector. Journal on Chain and Network Science, Vol. 2, 93-100.

Fudenberg, D. and J. Tirole, 1991. Game Theory. MIT Press, Cambridge, MA, USA.
Geyskens, I., J.-B.E.M. Steenkamp and N. Kumar, 1998. Generalization about trust in marketing channel relationships using meta-analysis. International Journal of Research in Marketing, Vol. 15, 223-248.

Goerzen, A. and P.W. Beamish, 2005. The effect of alliance network diversity on multinational enterprise performance. Strategic Management Journal, Vol. 26, 333-354.

Granovetter, M., 1985. Economic action and social structure: the problem of embeddedness. American Journal of Sociology, Vol. 91, 481-510.

Grossman, S.J. and O.D. Hart, 1986. The costs and benefits of ownership: a theory of vertical and lateral integration. Journal of Political Economy. Vol. 94, 691-720.

Gulati, R., 1995. Does familiarity breed trust? The implications of repeated ties for contractual choice in alliances. Academy of Management Journal, Vol. 38, 85-113.

Gulati, R. 1998. Alliances and networks. Strategic Management Journal, Vol. 19, 293-317.

Gulati, R. and H. Singh, 1998. The architecture of cooperation: managing coordination costs and appropriation concerns in strategic alliances. Administrative Science Quarterly, Vol. 43, 781-794.

Gulati, R., 1999. Network location and learning: the influence of networks resources and firm capabilities on alliance formation. Strategic Management Journal, Vol. 20, 397-420.

Gulati, R. and M. Gargiulo, 1999. Where Do Interorganizational Networks Come From? American Journal of Sociology, Vol. 104, 1439-1493.

Gulati, R., N. Nohria and A. Zaheer, 2000. Strategic Networks. Strategic Management Journal, Vol. 21, 203-216.

Gulati, R., P.R. Lawrence and P. Puranam, 2005. Adaptation in vertical relationships: Beyond incentive conflicts. Strategic Management Journal, Vol. 26, 415-440.

Gunasekaran, A. and E.W.T. Ngai, 2005. Build-to-order supply chain management: a literature review and framework for development, Journal of Operations Management, Vol. 23, 423-451.

Haehling v. Lanzenauer, C. and K. Pilz-Glombik, 2000. A Supply Chain Optimization Model for MIT's Beer Distribution Game. Zeitschrift für Betriebswirtschaft, Vol. 1, 101-116.

Hamel, G., Y.L. Doz and C.K. Prahalad, 1989. Collaborate with Your Competitors - and Win. Harvard Business Review. Vol. 67, 133-139.

Hamel, G., 1991. Competition for competence and inter-partner learning within international strategic alliances. Strategic Management Journal, Summer Special Issue, Vol. 12, 83-111.

Hanf, J. and C.-H. Hanf, 2005. Does food quality management create a competitive advantage? Paper prepared for the $92^{\text {nd }}$ EAAE seminar on Quality Management and Quality Assurance in Food Chains, March 2-4, Göttingen, Germany.

Hanf, J. and R. Kühl, 2005. Branding and its Consequence for the German Agribusiness. Agribusiness: An International Journal, Vol. 21, 177-189. 
Heide, J. and A. Miner, 1992. The shadow of the future: Effects of anticipated interaction and frequency of contact on buyerseller cooperation. Academy of Management Journal, Vol. 35, 265-291.

Hoffmann, J.M. and S. Mehra, 2000. Efficient Consumer Response as a supply chain strategy for grocery business. International Journal of Service Industry Management, Vol. 11, 365-373.

Holmstrom, B., 1982. Moral hazard in teams. Bell Journal of Economics, Vol. 13, 324-340.

Hutt, M.D., E.R. Stafford, B.A. Walker and P.H. Reingen, 2000. Defining the Social Network of a Strategic Alliance. Sloan Management Review, Vol. 41, 51-62.

Inkpen, A.C. and E.W.K. Tsang, 2005. Social capital, networks, and knowledge transfer. Academy of Management Review, Vol. 30, 146-165.

Jarillo, J.C., 1988. On strategic networks. Strategic Management Journal, Vol. 9, 31-41.

Kale, P. and H. Singh, 1999. Alliance capability and success. Best Paper Proceedings, Academy of Management Meeting, Chicago, USA.

Kale, P., H. Singh and H. Perlmutter, 2000. Learning and protecting of proprietary assets in strategic alliances: building relational capital. Strategic Management Journal Special Issue, Vol. 21, 217-237.

Kale, P., J.H. Dyer and H. Singh, 2002. Alliance capability, stock market response, and long term alliance success: the role of the alliance function. Strategic Management Journal, Vol. 23, $747-$ 767.

Kasperzak, R., 2004. Netzwerkorganisation und das Konzept der rechnungslegenden Einheit. Zeitschrift für Betriebswirtschaft, Vol. 74, 223-247.

Khanna, T., R. Gulati and N. Nohria, 1998. The dynamics of learning alliances: competition, cooperation, and relative scope. Strategic Management Journal, Vol. 19, 193-210.

Kim, H., R.E. Hoskisson and W.P. Wan, 2004. Power Dependence, Diversification Strategy, and Performance in Keiretsu Member Firms. Strategic Management Journal, Vol. 25, 613-636.

Kirsch, W., 1990. Unternehmenspolitik und strategische Unternehmensführung. Verlag Barbara Kirsch, München, Germany.

Kogut, B. and U. Zander, 1996. What firms do. Coordination, identity and learning. Organization Science, Vol. 7, 502-518.

Kotzab, H., 1999. Improving supply chain performance by efficient consumer response. A critical comparison of existing ECR approaches. Journal of Business \& Industrial Marketing, Vol. 14, 364-377.

Lane, P.J. and M. Lubatkin, 1998. Relative absorptive capital and interorganizational learning. Strategic Management Journal, Vol. 19, 461-477.

Lazzarini, S., F. Chaddad and M. Cook, 2001. Integrating Supply Chain and Network Analysis: The Study of Netchains. Journal on Chain and Network Science, Vol.1, 7-22.
Lee, H.L., 2004. The Triple-A Supply Chain. Harvard Business Review. Vol. 89 (10), 102-112.

Lee, H.L., V. Padmanabhan and S. Wang, 1997. The Bullwhip Effect in Supply Chains. Harvard Business Manager, Vol. 82 (10), 78 87.

Leiblein, M.J. and D.J. Miller, 2003. An empirical examination of transaction- and firm-level influences on the vertical boundaries of the firm. Strategic Management Journal, Vol. 24, 839-859.

Lindgreen, A., R. Palmer and J. Trienekens, 2005. Relationships within the supply chain: A case study. Journal on Chain and Network Science, Vol.5, 85-99.

Macharzina, K., 2003. Unternehmensführung. $4^{\text {th }}$ Edition, Gabler, Wiesbaden, Germany.

Madhok, A. and S.B. Tallman, 1998. Resources, transactions and rents: managing value through interfirm collaborative relationships. Organization Science, Vol. 9, 326-339.

March, J.G. and H.A. Simon, 1958. Organizations. Wiley, New York.

Mau, M. 2000. Supply Chain Management. Fachverlag Moderne Wirtschaft, Frankfurt, Dissertation, Germany.

McEvily, B. and A. Marcus, 2005. Embedded ties and the acquisition of competitive capabilities. Strategic Management Journal, Vol. 26, 1033-1055.

Medcof, J.W., 2001. Resource-based strategy and managerial power in networks of internationally dispersed technology units. Strategic Management Journal, Vol. 22, 999-1012.

Menard, C., 2004. The Economics of Hybrid Organizations. Journal of Institutional and Theoretical Economics Vol. 160, 1-32.

Menard, C. and P.G. Klein, 2004. Organizational Issues in the Agrifood Sector: Toward a Comparative Approach. American Journal of Agricultural Economics, Vol. 86, 750-755.

Mentzer, J.T., S. Min and Z.G. Zacharia, 2000. The Nature of Inter-firm Partnering in Supply Chain Management. Journal of Retailing, Vol. 76, 549-568.

Mohr, J. and J.R. Nevin, 1990. Communication Strategies in Marketing Channels: A Theoretical Perspective. Journal of Marketing, Vol. 36-51.

Mohr, J., R.J. Fisher and J.R. Nevin 1996. Collaborative Communication in Interfirm Relationships: Moderating Effects of Integration and Control. Journal of Marketing, Vol. 60, 103115.

Mulhern, F.J. and D.T. Padgett, 1995. The Relationship between Retail Price Promotion and Regular Price Purchase. Journal of Marketing, Vol. 59, 83-90.

Müller, M., S. Seuring and M. Goldbach, 2003. Supply Chain Management - Neues Konzept oder Modetrend. Die Betriebswirtschaft, Vol. 63, 419-439.

Müller, R.A.E., 2001. E-commerce and entrepreneurship in agricultural markets. American Journal of Agricultural Economics, Vol. 83, 1243-1249.

Müller-Stewens, G. and C. Lechner, 2001. Strategisches Management. Schäffer Poeschel, Stuttgart, Germany. 
Nadler, D.A. and M.L. Trushman, 1998. Competing by design. Executive Excellence, Vol. 15, 12-13.

Nalebuff, B.J. and A.M. Brandenburger, 1996. Co-opetition. Doubleday Books, New York, USA.

Nelson, R. and S. Winter, 1982. An Evolutionary Theory of Economic Change. Belknap Press: Cambridge, MA, USA.

Neves, M.F., 2003. Marketing and Network Contracts (Agreements). Journal on Chain and Network Science, Vol. 3, 7-19.

Obersojer, T. and H. Weindlmaier, 2006. About the Preparedness of Dairy Companies for ECR. In: Bijman, J., S.W.F. Omta, J.H. Trienekens, J.H.M. Wijnands and E.F.M. Wubben (eds.). International agri-food chains and networks. Wageningen Academic Publishers, 151-161.

Omta, A.W.F., J.H. Trienekens and G. Beers, 2001. Chain and network science: A research framework. Journal on Chain and Network Science, Vol.1, 1-6.

Otto, A. and H. Kotzab, 2001. Der Beitrag des Supply Chain Management zum Management von Supply Chains Überlegungen zu einer unpopulären Frage. Zeitschrift für betriebswirtschaftliche Forschung, Vol. 53, 157-176.

Pfeffer, J. and G.R. Salancik, 1978. The External Control of Organizations. Harper \& Row, New York.

Podolny, J. M. and K.L. Page, 1998. Network forms of organization, Annual Review of Sociology, 24, 1-24.

Porter, M.E., 1980. Competitive Strategy. Free Press, New York.

Reuer, J.J., and R. Ragozzino, 2006. Agency hazards and alliance portfolios. Strategic Management Journal, Vol. 26, 27-43.

Selten, R. and J.C. Harsanyi, 1972. A Generalized Nash Solution for Two-Person Bargaining Games with Incomplete Information. Mgmt. Science, Vol. 18, 80-106.

Seifert, D., 2004. Efficient Consumer Response: Supply Chain Management (SCM), Category Management (CM) and Collaborative Planning, Forecasting and Replenishment als neue Strategieansätze. $3^{\text {rd }}$ Edition, Verlag Hampp, Mering, Germany.

Sharma, A. and M. Levy, 1995. Categorization of Customers by Retail Sales People. Journal of Retailing, Vol. 71, 71-81.

Shaw, J.D., N. Gupta and J.E. Delery, 2000. Empirical organizationallevel examinations of agency and collaborative predictions of performance-contingent compensation. Strategic Management Journal, Vol. 21, 611-623.

Shelanski, H.A. and P.G. Klein, 1995. Empirical research in transaction cost economics: a review and assessment. Journal of Law, Economics and Organization, Vol. 11, 335-362.

Stroh, L.K., J.M. Brett, J.P. Baumann and A.H. Reilly, 1996. Agency theory and variable pay compensation strategies. Academy of Management Journal, Vol. 39, 1002-1016.

Stuart, T.E., 2000. Interorganizational alliances and the performance of firms: a study of growth and innovation rates in a hightechnology industry. Strategic Management Journal, Vol. 21, 791-811.
Sydow, J., 1991. Strategische Netzwerke in Japan. Zeitschrift für betriebswirtschaftliche Forschung, Vol. 43, 238-254.

Teece, D.J., G. Pisano and A. Shuen, 1997. Dynamic capabilities and strategic management. Strategic Management Journal, Vol. $18,509-533$.

Theuvsen, L., 2004. Transparency in netchains as an organizational phenomenon: exploring the role of interdependencies. Journal on Chain and Network Science, Vol. 4, 125-138.

Thome, R., R. Mautner and M. Pfister, 2004. Verbesserter Informationsfluss zwischen Handel und Hersteller. Zeitschrift für Studierende der Wirtschaftswissenschaft, Vol. 10, 1244-1254.

Thompson, J.D., 1967. Organizations in Action. McGraw-Hill, New York.

Tuten, T.L. and D.J. Urban, 2001. An Expanded Model of Businessto-Business Partnership Formation and Success. Industrial Marketing Management, Vol. 30, 149-164.

Ulaga, W. and A. Eggert, 2006. Value-based differentiation in business relationships: Gaining and sustaining key supplier status. Journal of Marketing, Vol. 70, 119-136.

Uzzi, B. and J.J. Gillespie, 2002. Knowledge spillover in corporate financing networks: embeddedness and the firm's debt performance. Strategic Management Journal, Vol. 23, 595-618.

Vilcassim, N.J. and P.L. Chintagunta, 1995. Investigating Retailer Product Category Pricing from Household Scanner Data. Journal of Retailing, Vol. 71, 103-128.

Webster, F.E. Jr., 1992. The Changing Role of Marketing in the Corporation. Journal of Marketing, Vol. 56, 1-17.

Werner, H. 2000. Supply Chain Management - Partnerschaft zwischen Lieferant und Kunde (I). Zeitschrift für Studierende der Wirtschaftswissenschaft, Vol. 6, 813-816.

Werner, H. 2000b. Supply Chain Management - Partnerschaft zwischen Lieferant und Kunde (II). Zeitschrift für Studierende der Wirtschaftswissenschaft, Vol. 7, 941-945.

White, S. and S. Siu-Yun Lui, 2005. Distinguishing costs of cooperation and control in alliances. Strategic Management Journal, Vol. 26, 913-932.

Williamson, O.E., 1975. Markets and Hierarchies: Analysis and Antitrust Implications. Free Press, New York, USA.

Williamson, O.E., 1985. The Economic Institutions of Capitalism. Free Press, New York, USA.

Williamson, O.E., 1991. Strategizing, economizing and economic organization. Strategic Management Journal, Vol. 12, Winter Special Issue, 75-94.

Williamson, O.E., 1999. Strategy research: Governance and competence perspectives. Strategic Management Journal, Vol. 20, 1087-1108.

Zaheer, A. and N. Vatakatraman, 1994. Determinants of electronic integration in the insurance industry: an empirical test. Management Science, Vol. 40, 549-567.

Zaheer, A. and G.G. Bell, 2005. Benefiting from network position: firm capabilities, structural holes, and performance. Strategic Management Journal, Vol. 26, 809-825. 
Zajac, E.J. and C.P. Olsen, 1993. From transaction cost to transactional value analysis: Implications for the study of interorganisational strategies. Journal of Management Studies, Vol. 30, 131-145.

Zajac, E.J., 1998. Commentary on "Alliance and Networks" by R. Gulati. Strategic Management Journal, Vol. 19, 319-321.

Zenor, M.J., 1994. The Profit Benefits of Category Management. Journal of Marketing Research, Vol. 31, 202-231.

Zylbersztjn, D. and E.M.M.Q. Farina, 1999. Strictly coordinated food-systems: Exploring the limits of the Coasian Firm. International Food and Agribusiness Management Review, Vol. 2, 249-265. 